\title{
PENGARUH PENDEKATAN ACCELERATED LEARNING TERHADAP KEMAMPUAN PEMECAHAN MASALAH MATEMATIS
}

\author{
Qomario \\ STKIP Al Islam Tunas Bangsa \\ qomario@stkipalitb.ac.id
}

\begin{abstract}
ABSTRAK
Tujuan penelitian ini untuk mengetahui pengaruh penggunaan pendekatan pembelajaran accelerated learning terhadap kemampuan pemecahan masalah matematis peseta didik. Penelitian ini merupakan penelitian eksperimen semu. Subyek penelitian, siswa kelas VA dan VB, pengujian hipotesisnya digunakan ujit. Hasil penelitian, perhitungan uji-t diperoleh $t_{\text {hitung }}=3,071$ sedangkan $t_{\text {tabel }}=$ 2,001, karena $t_{\text {hitung }}>t_{\text {tabel }}$ maka $\mathrm{H}_{0}$ ditolak dan $\mathrm{H}_{1}$ diterima. Jadi, dapat disimpulkan bahwa penggunaan pendekatan pembelajaran accelerated learning secara signifikan dapat memberikan pengaruh terhadap kemampuan pemecahan masalah matematis pada peserta didik.
\end{abstract}

Kata Kunci: Pendekatan Pembelajaran Accelerated Learning, Pemecahan Masalah Matematis.

\begin{abstract}
The aim of the study was to know the effect of accelerated learning on mathematics problem solving. This was a quasi experimental study. The subject was class VA and VB. The hyphotesis testing used t test calculation. The result was ttest result $=3,071$ and ttabel $=2,001$, because tobtain $>$ ttable so that $\mathrm{HO}$ was rejected and $H 1$ was accepted. Tjerefor, it can be concluded that accelerated learning was significantly influence in improving students mathematics problem solving.
\end{abstract}

Keywords: Accelerated Learning Approach, Mathematics Solving Problems

\section{PENDAHULUAN}

Pendidikan adalah kebutuhan hidup yang sangat penting bagi manusia, karena dengan pendidikan manusia dapat mengembangkan potensi yang ada pada dirinya melalui proses pembelajaran sehingga mampu memenuhi kebutuhan hidupnya. Berdasarkan Undang-Undang Sistem Pendidikan Nasional nomor 20 tahun 2003 mengatakan bahwa pendidikan adalah usaha sadar dan terencana untuk mewujudkan suasana belajar dan proses pembelajaran agar peserta didik secara spiritual keagamaan, pengendalian diri, kepribadian, kecerdasan, akhlak mulia, serta keterampilan yang diperlukan dirinya, masyarakat, bangsa dan Negara (Departemen Pendidikan Nasional. 2008). 
Pendidikan juga dapat diartikan sebagai proses pemberian bantuan dari guru kepada peserta didik terhadap perkembangan sikap, pengetahuan, jasmani dan rohani baik melalui pendidikan formal maupun non formal. Upaya untuk memenuhi tujuan pendidikan tersebut, maka diselenggarakan rangkaian pendidikan secara sengaja, berencana, terarah, berjenjang dan sistematis melalui lembaga formal seperti sekolah.Sekolah merupakantempat atau lembaga pendidikan yang menyediakan sejumlah bidang studi yang ditawarkan kepada peserta didik untuk dikuasai, salah satunya adalah pelajaran matematika.Matematika menurut para ahli dipandang sebagai ilmu dasar bagi ilmu pengetahuan lain. Untuk menguasai matematika diperlukan cara belajar yang berurutan, setapak demi setapak dan berkesinambungan. Hakekat matematika adalah kumpulan ide-ide yang bersifat abstrak, terstruktur dan hubungannya diatur menurut aturan logis berdasarkan pola pikir deduktif. Maka dari itu untuk belajar matematika harus dilakukan secara bermakna, dalam artian tidak bisa kalau hanya menerima dan dihafalkan saja melainkan harus banyak berlatih.

NCTM (National Council of Teacher Mathematics) (2000) menetapkan bahwa terdapat lima keterampilan proses yang perlu dimiliki peserta didik melalui pembelajaran matematika yang tercakup dalam standar proses, yaitu pemecahan masalah (problem solving), penalaran dan pembuktian (reasoning and proof), komunikasi (communication), koneksi (connection) dan representasi (representation). Keterampilan-keterampilan tersebut pada berpikir matematika tingkat tinggi (high order mathematical thinking) yang harus dikembangkan dalam proses pembelajaran matematika.

Wamington (2014), dalam surveinya tentang currentsituation on mathematics and science education in Bandung, menyatakanbahwa "pemecahan masalah matematika merupakan salah satu kegiatan matematika yang dianggap penting, baik oleh para guru maupun siswa di semua tingkatan mulai dari SD sampai SMU".Hal tersebut dianggap bagian yang paling sulit dalam mempelajarinya maupun bagi guru dalam mengajarkannya. Suatu masalah biasanya memuat suatu situasi yang mendorong seseorang untuk menyelesaikannya, akan tetapi tidak tahu secara langsung apa yang harus dikerjakan untuk menyelesaikannya.

Berdasarkan hasil wawancara yang telah peneliti lakukan pada tanggal 27 September 2017 dengan ibu Mauli selaku guru kelas V di SDN 5 Bumi Waras Bandar Lampung menunjukkan bahwa proses pembelajaran matematika cenderung membuat peserta didik merasa bosan dan takut, penyebab dari hal tersebut adalah pendekatan yang digunakan kurang bervariasi dan masih berpusat pada guru. Pada saat proses pembelajaran berlangsung peserta didik hanya menjadi pendengar dan malu untuk bertanya sehingga membuat peserta didik tidak mengerti dan merasa malas untuk belajar matematika. 
Peserta didik menganggap bahwa pelajaran matematika itu sulit, penyebab dari hal tersebut ialah dilihat dari proses pembelajaran yang berlangsung ketika peserta didik diminta untuk maju mengerjakan soal yang diberikan guru, mereka tidak bisa mengerjakannya dan ketika di beri PR mereka tidak mengerjakannya dirumah, sehingga berakibat nilai peserta didik rendah, rata-rata dibawah KKM (Kriteria Ketuntasan Minimun) dan dinyatakan tidak lulus.

Kondisi tersebut dipengaruhi oleh pembelajaran yang kurang bervariasi dan masih berpusat pada guru, sehingga peserta didik tidak bersemangat untuk belajar. Permasalahan lain juga terlihat pada kurangnya kemauan peserta didik dalam memanfaatkan waktu untuk belajar dengan sebaik-baiknya, sehingga peserta didik ingin secara instan tanpa belajar tetapi mendapat nilai yang baik, terutama ketika guru memberikan soal-soal mengenai pemecahan masalah. Salah satu alasannya yaitu belum mampu memahami permasalahannya, sehingga peserta didik tidak mampu melanjutkan ke tahap indikator pemecahan masalah selanjutnya.

Upaya untuk mengatasi permasalahan diatas guru harus bisa menciptakan kondisi belajar yang dapat membangkitkan semangat peserta didik, sehingga peserta didik dapat belajar secara aktif dan efisien. Salah satu pendekatan pembelajaran yang dapat diterapkan untuk mengatasinya ialah dengan menerapkan pendekatan accelerated learning.Pendekatan accelerated learning merupakan suatu pendekatan pembelajaran yang berpusat pada peserta didik, dengan demikian peserta didik menjadi lebih aktif dan tujuan pembelajaran akan tercapai dengan baik, terutama dalam hal pemecahan masalah matematis.

Hal tersebut sejalan dengan yang telah disampaikan oleh Desy Fajar (2011) dalam penelitiannya bahwa pendekatan accelerated learning juga merupakan suatu pendekatan yang dapat digunakan untuk meningkatkan kemampuan belajar peserta didik, sehingga peserta didik dapat belajar lebih cepat dan suasana belajar lebih menyenangkan dan terjadi interaksi yang aktif antar peserta didik sehingga pembelajaran dapat berlangsung lebih efektif.

Menurut Dave Meier (2002). Pendekatan accelerated learning juga akan membantu peserta didik dalam membangun sikap positif terhadap pelajaran matematika. Adapun tujuan dari pendekatan accelerated learning adalah menggugah sepenuhnya kemampuan belajar para peserta didik sehingga belajar menyenangkan dan memuaskan yang memberikan sumbangan sepenuhnya kepada kebahagiaan, kecerdasan, kompetensi dan keberhasilan.

\section{METODE PENELITIAN}

Metode penelitian yang digunakan dalam penelitian ini adalah metode kuantitatif atau penelitian kuantitatif karena data yang didapat berupa angkaangka dan penganalisisannya berupa analisis statistik. Jenis penelitian yang digunakan yaitu penelitian eksperimen. Peneliti melakukan perlakuan terhadap variabel bebas dan mengamati perubahan yang terjadi pada satu variabel terikat atau lebih. Jenis eksperimen yang digunakan dalam penelitian ini adalah Quasy Experimental Design, yaitu desain ini memiliki kelompok kontrol tetapi tidak 
berfungsi sepenuhnya untuk mengontrol variabel-variabel luar yang mempengaruhi pelaksanaan eksperimen (Sugiyono, 2010).

Teknik pengumpulan data yang digunakan sebagai berikut: Wawancara dilakukan pada guru mata pelajaran matematika mengenai pendekatan pembelajaran yang digunakan oleh guru dalam pembelajaran matematika pada peserta didik kelas V SDN 5 Bumi Waras Bandar Lampung. Dan dengan tes, Tes ini digunakan untuk mengetahui dan mengukur keberhasilan kemampuan pemecahan masalah matematis peserta didik dengan penerapan metode pembelajaran yang dilakukan. Tes yang akan dilakukan dalam penelitian ini berupa tes uraian (essay). Hasil tes kemampuan pemecahan masalah matematis peserta didik diberi skor sesuai dengan kriteria pensekoran. Berikut ini adalah tabel pensekoran hasil tes kemampuan pemecahan masalah matematis peserta didik yang disadur dari Lester, F. \& Krol, D dalam Krismanto dkk (2010)

\section{Tabel 1}

Pedoman Pensekoran Tes Kemampuan Pemecahan Masalah Matematis

\begin{tabular}{|c|c|c|}
\hline Skor & Kriteria & Keterangan \\
\hline 4 & $\begin{array}{l}\text { Semua yang berikut ini terpenuhi: } \\
\text { - } \quad \text { Jawaban yang diperoleh benar } \\
\text { - } \quad \text { Penjelasan jelas dan lengkap } \\
\text { - } \quad \text { Perhitungan matematis yang dilakukan benar }\end{array}$ & $\begin{array}{l}\text { Respon yang } \\
\text { patut dicontoh }\end{array}$ \\
\hline 3 & $\begin{array}{l}\text { Hanya terjadi salah satu dari yang berikut: } \\
\text { - } \quad \text { Jawaban salah karena sedikit kesalahan perhitungan } \\
\text { - } \\
\text { - } \quad \text { Penjelasan kurang jelas } \\
\text { Penjelasan kurang lengkap }\end{array}$ & $\begin{array}{l}\text { Respon yang } \\
\text { baik }\end{array}$ \\
\hline 2 & $\begin{array}{l}\text { Terjadi } 2 \text { dari } 3 \text { hal pada skor } 3 \text { di atas. Atau salah satu atau } \\
\text { lebih dari ciri-ciri berikut terjadi: } \\
\text { - } \quad \text { Jawaban tidak benar, namun disebabkan kesalahan } \\
\text { analisis (bukan kesalahan perhitungan) } \\
\text { - } \quad \text { Penjelasan tidak jelas atau membingungkan. } \\
\text { - } \quad \text { Ada kesalahan penerapan strategi penyelesaian }\end{array}$ & $\begin{array}{l}\text { Respon yang } \\
\text { kurang tepat }\end{array}$ \\
\hline 1 & $\begin{array}{l}\text { Jawaban tidak benar dan penjelasan (jika ada) dengan alasan } \\
\text { yang tidak benar dan strategi yang diterapkan tidak benar } \\
\text { atau membingungkan }\end{array}$ & $\begin{array}{l}\text { Respon yang } \\
\text { kurang }\end{array}$ \\
\hline 0 & $\begin{array}{l}\text { Kertas jawaban dalam keadaan kosong atau berisi catatan } \\
\text { yang tidak relevan untuk menjawab masalah. }\end{array}$ & $\begin{array}{l}\text { Tidak ada } \\
\text { respon }\end{array}$ \\
\hline
\end{tabular}

Selanjutnya skor yang diperoleh ditransformasikan menjadi nilai jadi dengan skala (0-100) maka rumus yang digunakan yaitu:

$$
\text { Nilai }=\frac{\text { SkorMentah }}{\text { SkorMaksimalIdeal }} \times 100
$$




\section{Teknik Analisis Data}

Sesuai dengan tujuan hipotesis yaitu terdapat pengaruh pendekatan accelerated learning terhadap kemampuan pemecahan masalah matematis siswa kelas V semester ganjilSDN 5 Bumi Warastahun ajaran 2017/2018, maka hipotesis itu akan diuji kebenarannya. Dalam penelitian ini penulis akan menggunakan uji-t berdasarkan variabel $\mathrm{X}_{1}$ (kelas eksperimen) dan $\mathrm{X}_{2}$ (kelas kontrol) yang akan diukur.

\section{HASIL PENELITIAN}

\section{Tes Kemampuan Pemecahan Masalah Matematis}

Setelah data dari semua variabel terkumpul selanjutnya digunakan untuk menguji hipotesis. Data tentang kemampuan pemecahan masalah matematis peserta didik pada materi operasi hitung aljabar yang sudah dipelajari, selanjutnya dapat dicari nilai tertinggi $\left(\mathrm{X}_{\mathrm{maks}}\right)$ dan nilai terendah $\left(\mathrm{X}_{\min }\right)$ pada kelas eksperimen maupun kelas kontrol. Kemudian dicari ukuran tendensi sentralnya yang meliputi rataan $(\overline{\mathrm{X}})$, median $(\mathrm{Me})$, modus $(\mathrm{Mo})$, dan ukuran variansi kelompok meliputi jangkauan (Q) dan simpangan baku (S) yang dapat dirangkum dalam penjelasan berikut ini:

\section{Kemampuan Pemecahan Masalah Matematis Peserta Didik Kelas Eksperimen}

Berdasarkan hasil tes yang diberikan kepada kelas eksperimen dengan pendekatan pembelajaran accelerated learning menggambarkan bahwa dari 30 peserta didik diperoleh rata-rata $(\overline{\mathrm{X}}) 76,667$, median $(\mathrm{Me}) 75$, modus (Mo) 75, varians $\left(\mathrm{S}^{2}\right)$ 151.016, simpangan baku (S) 12.289. Hasil nilai tes kemampuan pemecahan masalah matematis peserta didik kelas eksperimen dapat dilihat pada tabel dan grafik di bawah ini:

Tabel 2

Rekapitulasi Nilai Tes Kemampuan Pemecahan Masalah Matematis Peserta Didik

\begin{tabular}{lc}
\hline \multicolumn{1}{c}{ Statistika } & Nilai \\
\hline Jumlah Peserta Didik $(\mathrm{N})$ & 30 \\
\hline Nilai tertinggi $\left(\mathrm{X}_{\text {maks }}\right)$ & 100 \\
\hline Nilai terendah $\left(\mathrm{X}_{\text {min }}\right)$ & 50 \\
\hline Rata-rata $(\overline{\mathrm{X}})$ & 77 \\
\hline Median $(\mathrm{Me})$ & 75 \\
\hline Modus $(\mathrm{Mo})$ & 75 \\
\hline Varians $\left(\mathrm{S}^{2}\right)$ & 151.016 \\
\hline Simpangan baku $(\mathrm{S})$ & 12.289 \\
\hline
\end{tabular}

Rekapitulasi nilai tes kemampuan pemecahan masalah matematis peserta didik pada kelas eksperimen dalam bentuk grafik: 


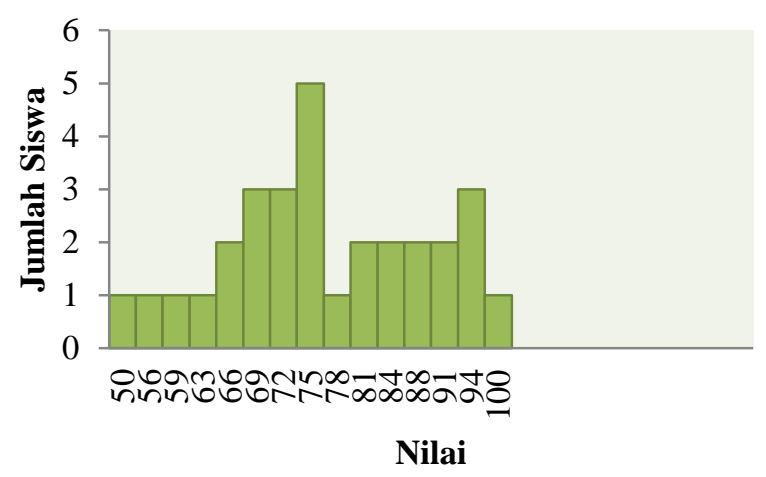

Gambar 1 Grafik nilai kemampuan pemecahan masalah matematis

Berdasarkan tabel dan grafik di atas dapat diketahui bahwa nilai tes kemampuan pemecahan masalah matematis pada kelas eksperimen memiliki nilai tertinggi sebesar 100 dan nilai terendah 50 .

\section{Kemampuan Pemecahan Masalah Matematis Peserta didik Kelas Kontrol}

Berdasarkan hasil tes yang diberikan kepada kelas kontrol dengan pembelajaran konvensional menggambarkan bahwa dari 31 Peserta didik diperoleh nilai rata-rata $(\overline{\mathrm{X}}) 65.323$, median (Me) 66, modus (Mo) 63, Varians $\left(\mathrm{S}^{2}\right)$ 277.826, simpangan baku (S) 16.668. Hasil nilai tes kemampuan pemecahan masalah matematis peserta didik kelas kontrol dapat dilihat pada tabel dan grafik di bawah ini:

Tabel 3

Rekapitulasi Nilai Tes Kemampuan Pemecahan Masalah Matematis Peserta Didik Kelas Kontrol

\begin{tabular}{lc}
\hline \multicolumn{1}{c}{ Statistika } & Nilai \\
\hline Jumlah Peserta Didik $(\mathrm{N})$ & 31 \\
\hline Nilai tertinggi $\left(\mathrm{X}_{\text {maks }}\right)$ & 97 \\
\hline Nilai terendah $\left(\mathrm{X}_{\text {min }}\right)$ & 22 \\
\hline Rata-rata $(\overline{\mathrm{X}})$ & 65,323 \\
\hline Median $(\mathrm{Me})$ & 66 \\
\hline Modus $(\mathrm{Mo})$ & 63 \\
\hline Varians $\left(\mathrm{S}^{2}\right)$ & 277.826 \\
\hline Simpangan baku $(\mathrm{S})$ & 16.668 \\
\hline
\end{tabular}

Rekapitulasi nilai tes kemampuan pemecahan masalah matematis peserta didik pada kelas eksperimen dalam bentuk grafik: 


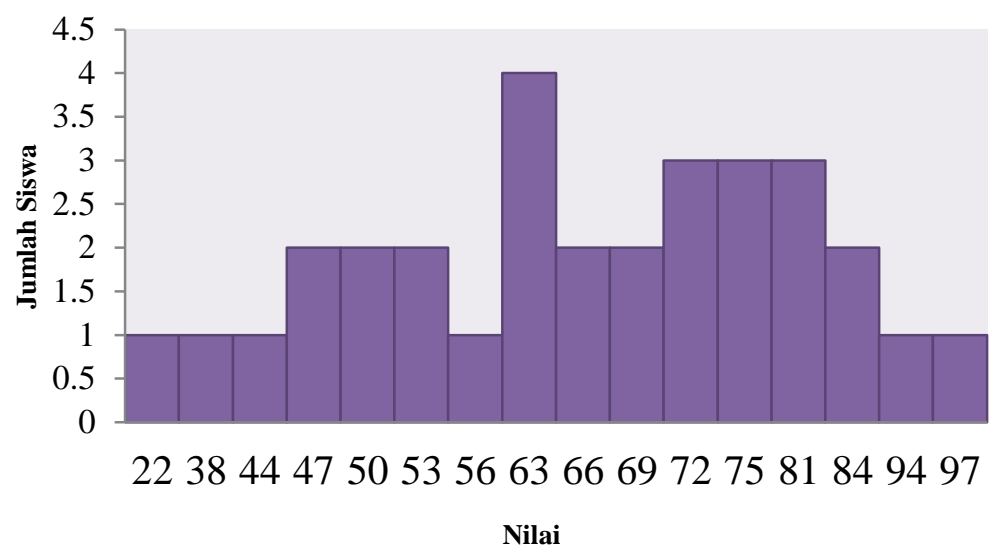

Gambar 2 Grafik nilai kemampuan pemecahan masalah matematis peserta didik kelas kontrol

Tabel dan grafik di atas menunjukkan bahwa nilai tertinggi dari tes kemampuan pemecahan masalah matematis peserta didik pada kelas kontrol sebesar 97 dan nilai terendahnya adalah 22. Hal ini disebabkan karena peserta didik di kelas kontrol kurang memperhatikan dan masih bermain pada saat proses pembelajaran berlangsung.

\section{Diagram kemampuan pemecahan masalah matematis kelas eksperimen dan kelas kontrol}

Proses penyajian data dengan rata-rata, median dan modus dengan kemampuan pemecahan masalah matematis kelas eksperimen dan kelas kontrol digambarkan dalam bentuk diagram batang di bawah ini:

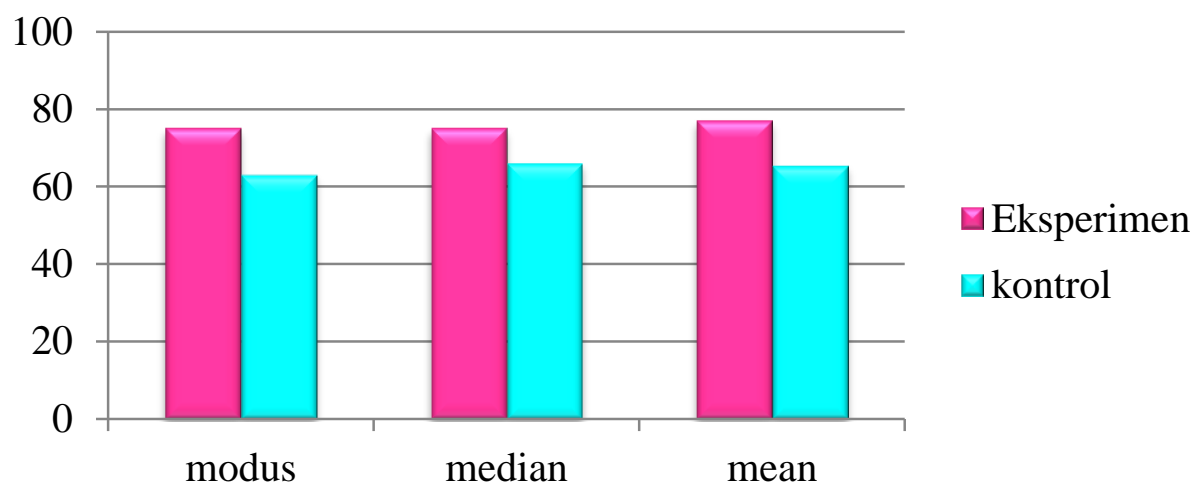

Gambar 3 Diagram batang kemampuan pemecahan masalah matematis kelas eksperimen dan kelas kontrol

Pada gambar diagram di atas menjelaskan bahwa nilai modus, median, dan mean pada kelas eksperimen, adapun nilainya yaitu modus (Mo) 75, median (Me) 75, dan Mean $(\overline{\mathrm{X}})$ 76,667. Pada kelas kontrol nilai modus, median dan meannya 
adalah modus (Mo) 63, median (Me) 66, mean $(\overline{\mathrm{X}})$ 65,323. Dengan demikian nilai modus median dan mean kelas eksperimen lebih tinggi daripada kelas kontrol.

\section{Pengujian Hipotesis}

Perhitungan uji hipotesis dilakukan untuk mengetahui ada atau tidaknya pengaruh dalam pembelajaran yang menggunakan pendekatan pembelajaran accelerated learning terhadap kemampuan pemecahan masalah matematis.Uji $\mathrm{t}$ diperoleh nilai $t_{\text {hitung }}=3,071$. Kemudian menghitung nilai $t_{\text {tabel }}$ dengan derajat kebebasan $=59$ dan taraf signifikan $(\alpha)=0,05$ diperoleh $t_{\text {tabel }}=2,001$. Lebih jelasnya dapat dilihat pada tabel berikut:

Tabel 4

Rekapitulasi Hasil Perhitungan Uji Hipotesis

\begin{tabular}{cccccc}
\hline Kelas & Jumlah sampel & Rata-rata & $\mathbf{t}_{\text {hitung }}$ & $\mathbf{t}_{\text {tabel }}$ & Kesimpulan \\
\hline Eksperimen & 30 & 77 & \multirow{2}{*}{3,071} & 2,001 & $\mathrm{H}_{1}$ diterima \\
\hline Kontrol & 31 & 65,323 & & & \\
\hline
\end{tabular}

Tabel diatas menunjukkan bahwa $t_{\text {hitung }}>t_{\text {tabelartinya }} \mathrm{H}_{0}$ ditolak dan $\mathrm{H}_{1}$ diterima.Dapat disimpulkan bahwa ada perbedaan antara kemampuan pemecahan masalah matematis menggunakan pendekatan accelerated learning dengan kemampuan pemecahan masalah matematis menggunakan pembelajaran konvensional.

\section{PEMBAHASAN}

Hasil penelitian menunjukkan bahwa rata-rata nilai akhir peserta didik baik pada kelas ekperimen maupun kelas kontrol meningkat.Hal tersebut dikarenakan pendekatan accelerated learning menekankan pada kemampuan pemecahan masalah matematis peserta didik pada materi aljabar selain mendapatkan penjelasan dari guru peserta didik juga mendapatkan penjelasan dari hasil diskusi kelompok, pada saat diskusi kelompok ini peserta didik mendapatkan penjelasan dari masing-masing kelompok melaui presentasi. Pada saat presentasi peserta didik diberikan kesempatan untuk berbicara untuk mengajukan pendapat,menanggapi pendapat peserta didik yang lain, dan mampu menghargai pendapat dari peserta didik yang lainnya, oleh karena itu semua peserta didik akan terlibat dalam pembelajaran. Pada akhir pembelajaran guru dan peserta didik menyimpulkan hasil pembelajaran.

Penggunaan pendekatan accelerated learning dalam proses pembelajaran intensitas dan keterlibatan peserta didik menjadi tinggi. Hal ini dapat menyebabkan peserta didik lebih perhatian dan bersemangat dalam mengikuti pembelajaran. Kondisi yang demikian mendorong peserta didik untuk lebih baik lagi dalam belajar agar hasilnya lebih baik. Hal ini disebabkan karena pendekatan accelerated learning ini memiliki beberapa kelebihan yaitu: Pertama dapat 
menciptakan suasana belajar tanpa stres, Karena accelerated learning tidak terpaku oleh satu cara atau jalan, melainkan menggunakan banyak jalan. Kedua dapat menumbuhkan rasa sosialisasi yang tinggi diantara peserta didik. Selama proses pembelajaran peserta didik bisa melakukan interaksi di dalam pembelajaran. Ketiga peserta didik menjadi lebih aktif dalam belajar. Karena pada pendekatan accelerated learning peserta didik disarankan untuk mempresentasikan pelajaran yang telah didapat.

Peserta didik di kelas kontrol diajarkan dengan menggunakan pembelajaran konvensional dimana proses pembelajaran masih berpusat pada guru. Proses pembelajarannya dimulai dengan pemaparan tentang materi yang akan dipelajari, sementara itu peserta didik memperhatikan dan mendengarkan hal-hal yang disampaikan oleh guru, Setelah itu guru melakukan tanya jawab untuk mengetahui apakah peserta didik sudah mengerti dengan apa yang disampaikan oleh guru. Selanjutnya, guru memberikan soal untuk dikerjakan secara individu.

Selama penulis melakukan penelitian di SDN 5 Bumi Waras Bandar Lampung, tidak menutup kemungkinan ada kendala-kendala yang penulis dapat, adapun kendala-kendala tersebut misalnya, banyak peserta didik yang bergurau pada saat pembelajaran sedang berlangsung dan masih banyak peserta didik yang kurang berkonsentrasi karena mengantuk, namun hal ini tidak begitu berarti dan masih bisa penulis hadapi selama proses pembelajaran berlangsung.

Penggunaan pendekatan accelerated learning yang telah dilakukan untuk melihat kemampuan pemecahan masalah matematis peserta dikdik mendapat respon yang baik dan berpengaruh positif pada peserta didik kelas eksperimen. Hal ini dilihat dari hasil tes akhir yang diperoleh peserta didik kelas eksperimen tinggi dari pada kelas kontrol.

\section{SIMPULAN}

Berdasarkan hasilanalisis data dan pengujian hipotesis yang telah dilakukan maka dapatdisimpulakan bahwa penerapan pendekatan pembelajaran accelerated learning pada kelas eksperimen memiliki pengaruh terhadap kemampuan pemecahan masalah matematispeserta didik. Hal ini dapat dilihat dari perhitungandengan menggunakan perhitungan uji-t dua sampel tidak berkorelasi dan diperoleh nilai $t_{\text {hitung }} \geq t_{\text {tabel }}$, sehingga $\mathrm{H}_{0}$ ditolak artinya penerapan pendekatan accelerated learning memberikan pengaruh yang signifikan terhadap kemampuan pemecahan masalah matematis pada pokok bahasan operasi hitung aljabar di kelas V SDN 5 Bumi Waras Bandar Lampung. 


\section{DAFTAR PUSTAKA}

Departemen Pendidikan Nasional. (2008). Undang-undang sistem pendidikan Nasional nomor 20 tahun 2003. Jakarta: Sinar Grafika

Desi, F (2011), Pengaruh Penerapan Accelerated Learning Untuk Meningkatkan Hasil Belajar Biologi Kelas XI SMA Surakarta, Skripsi, Surakarta, 2011, diakses tanggal 3 januari 2018 pukul 8:30 WIB

Dwi, W., A \& Krismanto, A. (2010). Pembelajaran Kemampuan Pemecahan Masalah Bangun Datar di SMP, Pusat Pengembangan dan Pemberdayaan Pendidikan Dan Tenaga Kependidikan (PPPPTK)

Meier, D. (2002). The Accelerated Learning Handbook. Cetakan ke-1. Bandung: Kaifa

NCTM. (2000). Principles and Standards for School Mathematics. Virginia: NCTM, Inc.

Sugiyono. (2010). Metode Penelitian Kuantitatif Kualitatif dan $R \& D$, Bandung : Alfabeta

Wamington ,R (2010), Upaya Meningkatkan Kemampuan Pemecahan Masalah Matematika Siswa Dengan Penerapan Teori Belajar Bruner Pada Pokok Bahasan Trigonometri di Kelas X SMA Negeri 1 Kualuh Hulu Aek Kanopan T.A. 2009/2010, skripsi, diakses tanggal 3 januari 2018 pukul 8:30 WIB 